The Geneva Papers on Risk and Insurance, 23 (No. 89, October 1998), 608-611

\title{
The IAIS - Tasks and Aims*
}

\author{
by Knut Hohlfeld**
}

The IAIS is a relatively new organisation. Since the mid-1980s insurance supervisors from around the world have met at the invitation of the National Association of Insurance Commissioners (NAIC) of the USA on the occasion of the NAIC's annual summer meeting to exchange experiences and meet with American insurance supervisors. But since insurance was becoming more and more international, the insurance supervisors agreed at their meeting in 1992 to take the necessary steps to constitute formally an International Association of Insurance Supervisors as sister organisation to the already well-known and operating very effectively Basle Committee on Banking Supervision (Basle Committee) and International Organisation of Securities Commissions (IOSCO) in the other two financial sectors, banking and securities. In 1994 the IAIS was incorporated as a not-for-profit corporation of the State of Illinois (USA) and held its first annual conference in Baltimore, Maryland (USA).

Originally the objective of the IAIS was mainly restricted to an exchange of experiences and information between insurance supervisors. But the IAIS members soon recognised that purely exchanging information did not sufficiently meet their need for cooperation. The association therefore was restructured and its objectives broadened. The objectives of the association are now:

- to cooperate together to ensure improved supervision of the insurance industry on the domestic as well as on an international level in order to maintain efficient, fair, safe and stable insurance markets for the benefit and protection of policyholders;

- to unite their efforts to develop practical standards for supervision of insurance that members may choose to apply;

- to liaise or cooperate with other relevant entities; Dresden.

* Speech presented at the $25^{\text {th }}$ General Assembly of the Geneva Association, June 25-27,

** Secretary General, International Association of Insurance Supervisors, c/o Bank for International Settlements, Basle. 
- to provide mutual assistance to safeguard the integrity of markets;

- to exchange information on their respective experiences in order to promote the development of domestic insurance markets.

The most significant change was the introduction of the task of developing practical standards for the supervision of insurance and giving guidance on insurance regulation and supervision for emerging market countries and countries in transition. These two targets have very quickly become the most important objectives of the association.

The development of international standards for insurance supervision will make it easier for regulators to strengthen their domestic supervision. Emerging insurance markets in particular would be assisted by international standards in establishing effective supervisory systems. This would help them to gain international recognition of their markets.

Although the proposed standards are not mandatory, there is a general expectation that market pressure will encourage their adoption once they have been developed.

The IAIS commenced work on developing standards and principles after the Annual Conference in Paris in October 1996, at which the by-laws were amended accordingly. The result of the first year's work was four papers which were approved at the Annual Conference in September 1997.

The first paper, "Insurance Supervisory Principles", sets out some general principles which identify subject areas that should be addressed in the legislation or regulation of each jurisdiction. It identifies the fundamental principles that underlie a sound regulatory and supervisory framework for insurance companies. The focus is more on the need for regulation than on the nature of that regulation, i.e. the paper concentrates on what to regulate rather than on how to regulate the insurance industry.

The second paper released by the IAIS is entitled "Guidance on Insurance Regulation and Supervision for Emerging Market Economies". This guidance is designed to encourage supervisors in emerging markets and in countries in transition to comply with the broad principles specified in the just mentioned iInsurance Supervisory Principlesî paper.

The IAIS further ratified a paper called "Principles Applicable to the Supervision of International Insurers and Insurance Groups and their Cross-Border Establishments". This paper is intended to improve the supervision of internationally active insurance companies. It states that all insurance establishments should be subject to effective supervision, that authorisation involving the cross-border activities should be subject to consultation between the relevant supervisors, and that provision should be made for external audits and for information sharing with other supervisors.

In addition to these papers, the IAIS also drafted a model Memorandum of Understanding (MOU) that can be used by supervisors to improve the exchange of information. This model MOU has been prepared as a guide and the IAIS recommends that supervisors should adopt it to facilitate cooperation with each other.

So much for the results of last year's work of the IAIS and the papers that have already been approved by the Association. What is next on the agenda? 
The IAIS is at present working on several further papers containing principles and standards for different areas of insurance supervision.

One of the most important areas of supervision is the licensing of insurance companies. It is generally recognised that licensing plays a significant role in ensuring efficiency and stability in the insurance market since the licence forms the basis for the activities of a company. The development of standards in this area is therefore of great importance. The corresponding paper will be finalised for approval at the next Annual Conference in September 1998.

Another working group is preparing a paper on on-site inspections. On-site inspections are considered to be a vital part of the supervisory process. They are an important tool for capturing reliable data and information in order to assess a company's current and prospective solvency, and for measuring its evolution and the reasons behind it. They are also a means of obtaining information and detecting problems that are not readily apparent from the ongoing inspection process. This paper on on-site inspections is also expected to be completed in time to be approved at the Annual Conference in September 1998.

Nearly ready for approval at the next Annual Conference is a paper on "Supervisory Standards on Derivatives". This paper provides guidance to supervisors in assessing how insurance companies should control the high risks in their handling of derivatives.

The IAIS has also begun working on solvency standards. The implementation of solvency requirements as well as methods for prudent assessment of solvency are important instruments or measures in ensuring satisfactory supervision on a domestic as well as on an international level. Because of the difficulties and the different principles applied worldwide, the work on solvency standards is a long-term project which will take several years to be finalised.

A further working group of the IAIS is dealing with issues surrounding electronic commerce and identifying any supervisory problems in this respect. Another working group of the IAIS is addressing matters relating to market conduct in the insurance sector.

All these activities of the IAIS aim at improving the standard of insurance supervision. Although the standards IAIS develops are not mandatory, the IAIS promotes the implementation of these standards - in hopefully most jurisdictions. The IAIS has therefore drafted a self-assessment programme for evaluating compliance by insurance supervisory authorities with the principles developed by the IAIS. Members are asked to complete the programme in 1998 and update it annually. This will provide a useful tool for members to assess their prudential framework and identify areas that need strengthening, which may spur national insurance supervisors to advocate the implementation of IAIS standards in national legislation.

Another means of promoting the incorporation of IAIS standards into national supervisory practice is regional training seminars for insurance supervisors from emerging market countries and countries in transition. Since October 1997 such training seminars were held in Mexico, the Caribbean, Zimbabwe and Poland. A further training programme for English-speaking African insurance supervisors is planned in South Africa at the end of June 1998. 
Besides the development of standards and training courses to implement prudent standards of insurance supervision into the jurisdictions worldwide another main topic of IAIS is the cooperation with other international organisations.

Members of the IAIS are already working together with IOSCO and the Basle Committee in the Joint Forum on Financial Conglomerates. The Joint Forum has the mandate to develop standards for the supervision of financial conglomerates and their cross-border business.

As a further step towards better cooperation the Technical Committee of the IAIS met with the Technical Committee of IOSCO and also with the Basle Committee, which in many regards has similar tasks concerning banking supervision to the IAIS concerning insurance supervision. In addition cooperation with the Basle Committee has been facilitated by the fact that the newly established independent IAIS Secretariat has taken its seat also in Basle at the Bank for International Settlements (BIS).

This is probably enough on the tasks and work of the IAIS for today.

The IAIS has just started its long march to become the worldwide recognised voice of the insurance supervisors. Although the IAIS is still young, it has a lot of good will and determination to make progress on the standards for prudent and effective supervision. I will refrain from comments on the structure of the IAIS so as not to overly prolong my speech.

The members of the IAIS already represent the insurance supervisory authorities of about 80 countries, comprising all the main insurance markets and many of the emerging market countries and countries in transition. Especially the last two groups profit from the work of the IAIS. I would very much welcome it if still more of them would join the IAIS. Certainly, a country may profit from the work of the IAIS even if its insurance supervisory authority is not a member of the IAIS. The results of its work are not restricted to members. The IAIS is interested in the implementation of prudent supervisory standards worldwide regardless of membership. But only membership enables the supervisory authority of a country to influence the work of the IAIS and also to profit from the exchange of experience and information at the different meetings of the Association.

I will close my remarks with an invitation to the IAIS's next Annual Conference which will be held from 28th September till 1st October 1998 in Canc'n, Mexico. Except for the General Business Meeting on the morning of the 1st October, all events of the Conference are also open to the insurance industry and other interested parties. Therefore, if you are interested in learning more about the IAIS and its work you would be welcome to attend. On the agenda of this year's conference will be panel discussions and workshops on electronic commerce, guarantee funds, accounting standards, reinsurance, on-site inspections, insurance supervisory framework in emerging markets and the recent GATS Agreement, and problems connected with mutual companies and demutualisation. If you are interested in attending, please let me know. You will get a registration form (address of the IAIS Secretariat: c/o Bank for International Settlements, CH-4002 Basle). 